\title{
ШЛЯХИ ПІДВИЩЕННЯ МОТИВАЦІЇ КУРСАНТІВ НЕФІЛОЛОГІЧНИХ ФАКУЛЬТЕТІВ ДО ВИВЧЕННЯ ІНОЗЕМНИХ МОВ
}

\begin{abstract}
Анотація. Досліджені шляхи підвищення мотивації курсантів нефілологічних факультетів до вивчення іноземних мов. В статті автор розглядае загальну типологію мотивації до навчання з точки зору психології,

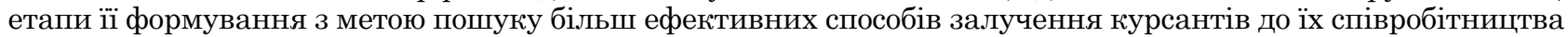
з викладачем в галузі вивчення інших мов. Він акцентуе увагу на внутрішній мотивації та можливостях ï постійного підтримання на високому рівні для стимуляції учбового процесу, а також зацікавленості в предметі навчання, підтверджуючи актуальність даної проблематики за допомогою проведення власних досліджень. Наукова новизна статті полягае в тому, що автор наголошуе на необхідності розвитку внутрішньої мотивації серед курсантів нефілологічних факультетів, які вивчають іноземну мову, через різні способи подачі інформації власне викладачем, який і є центром формування даної мотивації. За результатами дослідження було встановлено, що відношення курсантів до вивчення іноземної мови в більшості залежить від викладача, його активності, застосування ним методів взаемодії не тільки між викладачем та курсантом, але й курсантів між собою, його вміння зацікавити аудиторію та просто спілкуватися.
\end{abstract}

Ключові слова: мотивація, викладач, іноземні мови, навчання, курсанти нефілологічних факультетів, методи, саморозвиток.

Shchogoleva Nataliia

National Academy of the National Guard of Ukraine

\section{WAYS TO INCREASE THE MOTIVATION OF CADETS OF NON-PHILOLOGICAL FACULTIES TO STUDY FOREIGN LANGUAGES}

Summary. The article is devoted to the ways to increase the motivation of cadets of non-philological faculties in the process of learning foreign languages. At the beginning of the article the author considers the general types of motivation from the point of view of psychology, stages of their formation for search of more effective ways to involve cadets in learning other languages. The author emphasizes the internal motivation and the ability to maintain it at a high level to stimulate the learning process, as well as interest in the subject, confirming the relevance of this issue through his own research. The main stages how to develop motivation based on modern scientific research are discussed as a way how teacher can motivate cadets for study foreign languages. In this article the author pays attention to the great need to develop an intrinsic motivation among cadets of non-philological faculties who study a foreign language, through different ways of presenting information by the teacher, who is the center of this motivation. Nevertheless, the attitude of cadets to learn a foreign language mostly depends on the teacher, his activity, his use of different methods of interaction not only between a teacher and his cadets, but also cadets among themselves, the ability of the teacher to interest the audience and just communicate. What is special, according to the research conducted by the author of the article, is that it is very important to maintain a constant feedback in order to repeat a particular topic with cadets and to develop the teacher's work with cadets "on the same wave". So, the author provides comments on the following point that a center of motivation of high level is a teacher who knows how to convey information correctly, organize a process of learning and cooperation, as a result - stimulate cadets for finding new knowledge and self-development. The way to increase motivation is not only to focus the teacher on what he says, but also in the ability to teach cadets to understand the need to learn a foreign language as a promising discipline in the future.

Keywords: motivation, teacher, foreign languages, education, cadets of non-philological faculties, methods, self-development.

Постановка проблеми. На сучасному ета1 пі розвитку вищої освіти одне 3 найважливіших місць займає вивчення іноземної мови, що являе собою одну з вирішальних складових формування висококваліфікованих спеціалістів, здатних до адаптації в будь-яких умовах. Як результат, дуже гостро постає проблема підвищення мотивації тих, кого ми навчаємо, в такому випадку мова йде про курсантів нефілологічних фракультетів НАНГУ, що вивчають іноземну мову в системі загальної вищої освіти. Вчені в області педагогіки та психології приділяють багато уваги питанню мотивації. Протягом навчання 3 часом рівень мотивації курсантів знижуеться через необхідність подолання певних труднощів та, як результат, зниження рівня зацікавленості до дисципліни, пов'язаної з розвитком навичок іншомовного спілкування. Таким чином, пошук шляхів підвищення мотивації курсантів до вивчення іноземних мов $є$ наразі актуальним та займає важливе місце в галузі педагогіки серед викладачів військових навчальних закладів.

Аналіз останніх досліджень та публікацій. Дослідження даної проблеми такими авторами, як С.У. Гончаренко, Дж. Келлер, О.М. Леонт'єв, С.Л. Рубінштейн, показали, що мотивація спонукає до навчання та досягнення найкращих результатів. В залежності від застосування викладачем тих чи інших заходів рівень мотивації може змінюватися. Для едективності навчання іноземним мовам мотивацію слід постійно підтримувати, спираючись на різні психологічні аспекти та застосовуючи різні методи для заохочення суб'єктів до навчання. 
Виділення невирішених раніше частин загальної проблеми. В системі вищих військових навчальних закладів питання про мотивацію $е$ досить складним, оскільки навчання має власну специфіку та вимагає особливого підходу, який сприятиме формуванню бажання курсантів до пошуку нових знань, а саме опановування іноземної мови. Спираючись на результати останніх досліджень, слід зауважити, що шляхи підвищення мотивації курсантів нефілологічних факультетів до вивчення іноземних мов були досліджені недостатньо.

Формулювання цілей статті. Отже, головною метою написання даної статті $є$ пошук шляхів мотивації курсантів нефрілологічних факультетів НАНГУ до вивчення іноземних мов.

Для досягнення мети автором статті були поставлені наступні завдання:

- розглянути загальну типологію мотивації до навчання з точки зору психології;

- розглянути основні етапи формування та розвитку мотивації, які були розроблені сучасними науковцями;

- звернути увагу на перспективи залучення етапів формування та розвитку мотивації до роботи з курсантами під час навчання іноземній мові;

- встановити шляхи підвищення мотивації курсантів нефілологічних фокультетів НАНГУ до вивчення іноземних мов, спираючись на власні дослідження.

Під час добірки та аналізу матеріалу для статті, було виявлено, що серед найбільш результативних шляхів підвищення мотивації курсантів нефрілологічних факультетів НАНГУ до вивчення іноземних мов слід виділити наступні:

- правильний підбір викладачем способу подачі тіеї чи іншої інформації, її новизна;

- врахування індивідуального підходу;

- підтримання зворотного зв'язку;

- застосування інтерактивних методів навчання;

- перегляд коротких відео сюжетів, бажано с зоровою опорою;

- додаткове обговорення теми, яка розглядаеться протягом заняття;

- наявність особистих викладацьких якостей.

Виклад основного матеріалу дослідження. По-перше, слід зробити посилання на загальну типологію мотивації. Вона буває зовнішньою та внутрішньою. Внутрішня мотивація залежить від внутрішнього середовища (викладач, навчальна група, оточення). Зовнішня мотивація обумовлена значущістю інформації про країну, мова якої вивчаеться, її культуру та історію, усвідомленням важливості мови для реалізації потреб [3]. Внутрішня мотивація е більш суттевою та впливовою під час вивчення іноземної мови, оскільки вона формуе особисте відношення курсанта до навчання та власне усвідомлення необхідності в розширенні свого кругозору та покращення своїх навичок володіння іноземною мовою й самовдосконалення. Внутрішня мотивація в більшості залежить від способу подання інформації та ступеню зацікавленості курсанта в даному предметі. Тоді як зовнішню мотивацію підтримуе викладач шляхом оцінювання, поточного контролю, іноді примусу. Але, на жаль, цей спосіб мотивації не дає постійного результату.
Таким чином, викладачеві важливо знати потреби, якими керуються курсанти, та постійно підтримувати мотивацію навчання на високому рівні, звертаючи увагу на формування та розвиток саме внутрішньої мотивації [3].

За американцем Джоном Келлером, мотивація включає чотири основних етапи: увага, значимість, впевненість та задоволення від англійської attention, relevance, confidence, satisfaction [4].

Незважаючи на черговість етапів, перший (увага) повинен виконуватися протягом усього навчання. Залучення уваги людини до курсу навчання - крок, без якого процес не буде розпочато. Але і в процесі навчання необхідно постійно підтримувати увагу, не допускаючи нудьги. Допомогти в цьому можуть зміна способів донесення індормації, залучення до різних видів діяльності та різні стилі спілкування (включаючи гумор і неформальні підходи).

Значилість - важливість процесу і результату навчання для учня, в нашому випадку мова йде про курсанта. Це та сила, яка підштовхуе його самостійно прагнути пізнати щось нове всупереч існуючим перешкодам. На цьому етапі необхідно допомогти учневі (курсанту) побачити зв'язок між курсом навчання та його очікуванням, практичну цінність навчання для нього особисто. Для вирішення подібного завдання необхідно «прислухатися» до потреб учня (курсанта), вміти говорити з ним «однією мовою» [4].

Bnевненість - це переконання людини в тому, що він володіє достатніми можливостями для навчання. За відсутності впевненості в успіху, результат навчання зводиться до нуля.

У тому випадку, коли учень (курсант) має впевненість, роль викладача в процесі навчання є мінімальною. Викладачеві достатньо лише надати поштовх, задати напрямок для саморозвитку свого учня (курсанта) та пошуку ним нових знань.

До кінця процесу навчання зростає роль задоволеності. До цього часу у учнів (курсантів) з'являються втома, сумніви в застосовності знань, які вони отримують, та інше. Для подолання подібного настрою необхідно допомогти учням (курсантам) в пошуку відповідності результатів навчання 3 практичними потребами. Також бажано залучати позитивні мотиваційні заходи в вигляді винагороди, похвали тощо.

3 моеї власної точки зору, для отримання максимально позитивних результатів, викладачеві обов'язково слід враховувати всі етапи формування та розвитку мотивації, про які йшла мова вище, в процесі роботи з курсантами та їх навчання іноземній мові.

Для пошуку шляхів підвищення мотивації та заохочення курсантів нефілологічних факультетів до вивчення іноземної мови було проведено соціологічне опитування серед представників декількох спеціальностей різних років навчання. За результатами дослідження було встановлено, що відношення курсантів до дисципліни в більшості залежить від викладача, способу подачі ним інформації, його вміння зацікавити аудиторію та просто спілкуватися. Спираючись на етапи формування мотиващії, виділені Джоном Келлером, це - перші два особливих фоктора, на які викладач іноземної мови повинен 
звернути увагу. Далі за етапами маємо впевненість та задоволення. Саме вони можуть бути сформовані завдяки ерудованості, ентузіазму викладача та індивідуального підходу до кожного курсанта окремо. Обов'язково викладачеві необхідно підтримувати й зворотній зв'язок (як вважають курсанти). Він, в свою чергу, сприятиме підтримці постійного контакту та розуміння викладачем якості засвоєння матеріалу й можливої необхідності повторення тієї чи іншої теми.

Окрім всього зазначеного вище, дослідження показало, що мотиващію можна підвищити завдяки новизні інформащї, яка подається, а також застосуванню викладачем різноманітних інтерактивних методів навчання: дискусії, семінару, опитування тощо. Особливо результативним виявився ігровий метод, як один 3 методів взаємної діяльності між викладачем та курсантами, а також в групі в цілому. Даний метод сприяе психологічній розрядщі на занятті, розвитку колективності, можливості прояву творчих та комунікативних здібностей кожного курсанта. А оскільки основою для розвитку мовлення є спілкування, це - один з найкращих методів оволодіння іноземною мовою.

Під час практичного застосування різних форм та засобів навчання для заохочення курсантів до вивчення іноземної мови було виявлено, що є дуже необхідним перегляд коротких відеосюжетів під час занять, бажано з субтитрами. Ці відео сюжети, в свою чергу, завдяки наявності зорової опори, допомагають краще зрозуміти зміст інформації та відтворити ії іноземною мовою, подолати мовний бар'ер й створити відчуття впевненості в своїх можливостях. Додаткове обговорення змісту того, що переглядалося, в цьому випадку також не є зайвим, а тільки впливає на позитивний результат.

Висновки 3 даного дослідження. Таким чином, спираючись на все, сказане вище, можна зробити висновок, що для досягнення максимальної ефрективності та результативності проведення занять 3 вивчення іноземної мови для курсантів нефрілологічних фракультетів вищих військових навчальних закладів, а саме курсантів НАНГУ, викладачам бажано застосовувати різні види мотивації як зовнішню, так і внутрішню. Оскільки кожний з цих видів мотивації стимулює учнів до діяльності по-своєму. Але слід пам'ятати про те, що саме внутрішня мотивація, яка формуе власне бажання учнів до навчання та пошуку нових знань, несе за собою великі досягнення i, як результат, потребу курсантів у самовдосконаленні й саморозвитку, яке, в свою чергу, викликае потребу у вивченні іноземної мови.

Оскільки етапи формування та розвитку мотивацї вже розроблені сучасними науковцями, викладач, починаючи роботу 3 тією чи іншою групою курсантів, повинен враховувати їі психологічні особливості для фрормування постійної активності під час занять та підтримки інтересу до дисципліни.

Спираючись на результати дослідження, проведеного шляхом соціологічного опитування, автор статті наголошуе на тому, що основні шляхи підвищення мотивації до вивчення іноземної мови курсантами нефілологічних фракультетів викладачеві слід шукати в самому собі. Бо все залежить від його ораторських здібностей, рівня досвідченості та обізнаності не тільки в сфреpi дисципліни, яку він викладає, але й життя в цілому, здатності цікаво подавати інформацію та формувати серед курсантів стимул до навчання. Постійний інтерес до вивчення іноземної мови підтримується, коли викладач шукає щось нове, виявляе ентузіазм та повагу до тих, кого він навчає, підбирає різноманітні методи інтерактивної діяльності протягом занять, має зворотний зв'язок з курсантами, враховуючи їх власні потреби в системі навчання. За наявності цього результат буде максимальним.

Головна мета викладача - не тільки сконцентрувати увагу своїх учнів на тому, про що він говорить, але й навчити їх розуміти необхідність вивчення іноземної мови, як перспективної дисципліни в майбутньому. Тоді шлях до розвитку мотивації високого рівня буде відкрито.

\section{Список літератури:}

1. Gardner R.C. Language Learning Motivation: The Student, the Teacher, and the Researcher. Texas Papers in Foreign Language Education. P. 2-4.

2. Арістова Н.О. Формування мотивації вивчення іноземної мови у студентів вищих нелінгвістичних навчальних закладів : дис. ... канд. пед. наук : 13.00.04. Київ, 2009.

3. Гальскова Н.Д., Гез Н.И. Теория обучения иностранным языкам: Лингводидактика и методика. Москва : Издат. центр «Академия», 2004. С. 151.

4. Гончаренко С.У. Український педагогічний словник. Київ : Либідь, 1997. 376 с.

5. Гришкова Р.О. Психолого-педагогічні умови особистісно орієнтованого вивчення іноземної мови. Наук. записки КМА. Т. 18. Київ, 2000. С. 35-36.

6. Дж. Келлер. Модель мотивации к обучению. 2006.

7. Леонтьев А.Н. Избранные психологические произведения : В 2 т. Москва : Педагогика, 1983. Т. 2. 320 с.

8. Бакаєва Г.Є., Борисенко О.А., Зуенок I.I. та ін. Програма з англійської мови для професійного спілкування. Київ : Ленвіт, 2005. 119 с.

9. Рубинштейн С.Л. Основы общей психологии. Москва : Учпедгиз, 1946. 704 с.

10. Щукин А.Н. Обучение иностранным языкам: Теория и практика. Москва : Филоматис, 2004. С. $161-162$.

11. Якобсон П.М. Психологические проблемы мотивации в поведении человека. Москва : Просвещение, 1969. $317 \mathrm{c}$.

\section{References:}

1. Gardner R.C. Language Learning Motivation: The Student, the Teacher, and the Researcher. Texas Papers in Foreign Language Education. P. 2-4.

2. Aristova N.O. (2009) Formuvannya motivatsii vivchennya inozemnoï movi u studentiv vishchikh nelingvistichnikh navchalnikh zakladiv [Formation of motivation to learn a foreign language in students of higher non-linguistic educational institutions]: dis. ... kand. ped. nauk: 13.00.04. Kyiv. 
3. Galskova N.D., Gez N.I. (2004) Teoriya obucheniya inostrannym yazykam: Lingvodidaktika i metodika [Theory of teaching foreign languages: linguodidactics and methodology]. Moscow: Izdat. tsentr "Akademiya".

4. Goncharenko S.U. (1997) Ukrainskiy pedagogichniy slovnik [Ukrainian pedagogical dictionary]. Kyiv: Libid.

5. Grishkova R.O. (2000) Psikhologo-pedagogichni umovi osobistisno orientovanogo vivchennya inozemnoï movi [Psychological and pedagogical conditions of personality-oriented learning of a foreign language]. Nauk. zapiski KMA. T. 18. Kyiv.

6. Dzh. Keller (2006) Model motivatsii k obucheniyu [Model of motivation to learn].

7. Leontyev A.N. (1983) Izbrannyye psikhologicheskiye proizvedeniya [Selected psychological works]: V 2 t. Moscow: Pedagogika. T. 2.

8. Bakaeva G.E., Borisenko O.A., Zuenok I.I. ta in. (2005) Programa z angliyskoi movi dlya profesiynogo spilkuvannya [English language program for professional performance]. Kyiv: Lenvit.

9. Rubinshteyn S.L. (1946) Osnovy obshchey psikhologii [Fundamentals of General Psychology]. Moscow: Uchpedgiz.

10. Shchukin A.N. (2004) Obucheniye inostrannym yazykam: Teoriya i praktika [Teaching foreign languages: theory and practice]. Moscow: Filomatis.

11. Yakobson P.M. (1969) Psikhologicheskiye problemy motivatsii v povedenii cheloveka [Psychological problems of motivation in human behavior]. Moscow: Prosveshcheniye. 